\title{
Merlinda Bobis's Poem-Plays: Reading Ethics and Identity Across Cultures
}

\author{
Dolores Herrero, Universidad de Zaragoza, España.
}

The work of Filipino Australian Merlinda Bobis deserves critical and academic assessment as an example of contemporary creative writing by women that defies longestablished notions and classifications and recasts traditional myths and genres from a feminist and multi/ transcultural perspective. This paper therefore aims to study Bobis's efforts to do away with rigid and monolithic notions of culture and identity by putting forward new and challenging hybrid forms and, in particular, to analyse the ways in which Bobis's poem-plays question patriarchal binary divisions and definitions of morality by offering an alternative feminist ethics of care.

\section{Feminism and the Return of Ethical Criticism}

Classical definitions of morality, Daphne Grace Haney has argued (2002, 143), with their emphasis upon supposedly detached and aseptic analyses of right-wrong and their endorsement of rights and rules, have been questioned and rejected by feminists of all kinds in the past three decades as predominantly masculine theories. As has been well documented, since Plato, women in the western world, and more especially those living in colonized territories, have been systematically associated with the illogical and the emotional, and have been placed outside moral and political spheres. The Romans defined morality as being exclusively masculine: the word 'virtue' comes from the root 'vir,' meaning man. The Enlightenment only corroborated this view, the German 
thinker Kant going as far as to assert in his moral philosophy: 'of course, I exclude women, children, and idiots' (in Hekman 1995, 36). To counter the lethal effects of patriarchal morality, many women writers, aware as they were of the dangers of relying on generalizing notions and labels, have nonetheless developed an alternative ethics of care based on principles of sympathy, nurturing and compassion. Carol Gilligan’s works, in particular her book In a Different Voice (1982), can be said to have pioneered the development of this movement. Gilligan states that 'the moral imperative' that emerges from a woman's perspective is 'an injunction to care, a responsibility to discern and alleviate the real and recognizable trouble of this world' $(1982,19)$. While men's main concern is not to interfere with the rights of others, Gilligan goes on to argue, women are chiefly concerned with responsibility and relationships rather than rights and rules. In other words, women's moral judgements are, on the whole, not normative, but contextual and narrative. In her more recent work (1995, 121-26), Gilligan establishes a clear distinction between a feminine ethic and a feminist ethic of care. A feminine ethic is one that entails social obligations and self-sacrifice, and which is therefore concomitant with patriarchy. A feminist ethic of care begins with connection, that is, a thorough appreciation of how human lives and emotions are interconnected, to the point of becoming the voice of resistance.

However true these views may be, they should never be considered in a vacuum, that is, as general assumptions that apply to all women in exactly the same way. Many other social, economic, cultural and generational distinguishing factors should also be taken into consideration when analyzing particular authors, works and situations. As is well known, recent feminist scholarship has brought to the fore the heterogeneity of postcolonial experiences and the diversity of women's lives within them. ${ }^{1}$ Chandra Talpade Mohanty, to give one example, warns against the temptation to use the general or universal term 'women' in order to refer to the specific historical and material reality of particular groups of women. The work of postcolonial feminist critics has also been fundamental in bringing this clarification to the surface. Spivak's writings on the impossibility of subaltern (third world) women being heard, to mention but one of the

\footnotetext{
${ }^{1}$ See, for instance, Talpade Mohanty et al. (1991), Bulbeck (1998), and Ghandi (1998).
} 
most widely known critical works in this field, is an outstanding example. As she put it in her seminal work 'Can the Subaltern Speak?' (1988), postcolonial subjects, and particularly women, are trapped within a space that enforces their silence. Yet, the degree of alienation and repression they suffer will vary depending on their specific circumstances. The term 'Third World Woman' should not therefore be taken as universal and monolithic. Nevertheless, the world-wide silencing of women, she goes on to argue, could be extrapolated to the whole colonial process and be thus indicative of patriarchal and colonial morality. Winnie Tomm (in Haney 2002, 144) reaches a similar conclusion when she claims: 'Patriarchal morality is based on the desire for power over the other, beginning with sexual power over women and extending to political power over nations. The politics of sex has the same source as the politics of wars: ignorance, fear, and hostility toward the other.' To put it differently, ethics in the developing world has to do, not only with the simple survival of human beings, but also with the survival of sheer humanness. Ethics should not therefore be regarded as a secondary academic matter, but as utterly fundamental for human survival. Moreover, to claim the well-known feminist tenet that 'the personal is always political' inevitably implies a discussion of an ethics that calls for responsibility in our actions and solidarity and reciprocity in our interactions.

The women's contributions so far mentioned were not an isolated phenomenon, however. Although clearly feminist, they should also be regarded as part of a much wider critical trend, namely, ethical criticism. The 1980s and 1990s witnessed the emergence of what critics have labeled as an ethical turn, partly produced as a reaction against the cultural radicalism and relativism propounded by certain ideological conceptions of the postmodern era. The return of ethical criticism has not been, however, a homogeneous phenomenon. Critics like Wayne Booth (1988) and Martha Nussbaum (2001), to mention but two well-known examples, have led an attempt to reintroduce the values of liberal humanism associated with Matthew Arnold (1882) and F. R. Leavis (1933, 1948, 1982) in the academia, while J. Hillis Miller (1987), Andrew Gibson (1999) and Christopher Falzon (1998), among others, have made the case for a criticism informed by the deconstructive ethics mainly put forward by Jacques Derrida 
(1989, 1991, 2001) and Emmanuel Levinas in his seminal works Totality and Infinity (1961) and Otherwise Than Being or Beyond Essence (1974). The feminist works previously mentioned might be seen as anticipating and/or corroborating some of the conclusions reached by the latter cluster of critics, mainly concerned with defining and advocating a postmodern post-foundational ethics. This ethics clearly asserts that it is possible to make ethical claims without relying on normative codes, categorical imperatives, or universal moral principles because 'there are no categories or concepts knowable prior to what becomes the decisive ethical moment in Levinas' philosophy: the encounter with the singular, irreducible Other' (Kotte 2001, 71). According to Levinas, ethical responsibility is prompted by the encounter with the Other, or 'the face,' as he also refers to it. For him, the Other is always radically different and resists being transformed or appropriated. Our encounters with the Other are often ruled by our attempts to assimilate it and transform it in terms of our categories of understanding. To put it differently, we strive to reduce the Other to the Same, which turns this ethical moment par excellence into a rather unethical imposition. This has been, according to Andrew Gibson, the characteristic mode and ultimate sin of western philosophy, which has systematically tried to 'speak of and therefore master the other as whole, to reduce the other to the terms of the same' $(1999,65)$. Is there a way to escape this 'unethical' impulse towards the Other? The only answer for Levinas is to confidently open ourselves up to the experience of reciprocity and alterity. In other words, meeting the Other on ethical grounds implies assuming that there are no monolithic truths, that we cannot possibly be in absolute control, nor be in possession of the absolute truth, and that the subject is in constant dialogue and transformation, since our encounter with the world involves a reciprocity, a two-way movement or interplay between ourselves and the world that inexorably turns our self into an ever-changing entity.

As can be deduced after reading Merlinda Bobis’s poem-plays Promenade (1998b) and Cantata of the Warrior Woman (1998a), the main object of analysis of my paper, this author is mainly concerned with writing as an 'ethical' means, not only of doing away with fixed and rigid categories and classifications, but also of liberation and celebration of a shared experience among women, especially women who have been suppressed by 
the combined oppression of religion, patriarchy and colonialism. These works clearly echo and enforce the ethical postulates so far discussed.

\section{Merlinda Bobis and the Filipino Traditions of Writing}

To understand Merlinda Bobis’s position, one must take a number of factors into consideration. First, she was born in the Philippines but now lives in Australia. In other words, she has been carried across different cultures and cannot therefore be defined by making exclusive reference to any of them. Second, unlike other Filipino women authors, who have decided to write in only one language (either English or their mother tongue), Bobis has deliberately chosen to write in both Filipino and English, thus showing her defiant willingness to make use of what she regards as her rich bicultural heritage. ${ }^{2}$ Writing in Filipino, Bobis, like many other Filipino artists, contributes to preserving the culture and values of the indigenous peoples of her home country. It is undeniable, as Marra Pl. Lanot affirms, that these cultural minorities, as elsewhere in the world, are relegated to the margins; their artistic manifestations are neither studied nor disseminated because these groups are far from the centres of media and education and consequently do not form part of mainstream culture (1997, para. 5). However, it is also true that 'unlike some nations subjugated by foreign power, the Philippines cradles indigenous people .... They still preserve and practise their ancient beliefs, customs, and traditions’ (1997, para. 4), despite the long periods of Spanish and American colonization they suffered in the past. On the other hand, Bobis's poetical work in English, some of which I will focus on in this paper, can be seen as part, and inheritor,

\footnotetext{
${ }^{2}$ As has been thoroughly documented, the question of whether to use English or Tagalog/Filipino as writing languages has been quite a complex and thorny issue for most Filipino authors, since the privileging and enforcement of one or the other has mainly depended on the shifting phases of Filipino history in the twentieth century. Far from resenting English as the oppressor's tongue (in 1898 the Treaty of Paris ended the Spanish-American war and transferred sovereignty over the Philippines from Spain to the United States), most early-twentieth-century writers, especially women, welcomed it as an instrument of cultural advancement (because women and men began writing in English at the same time, the first generation of women writing in English did not suffer the sorts of anxieties that afflicted women in the West). Yet, the inauguration in 1935 of the Philippine Commonwealth, which allowed for local autonomy while retaining U.S. tutelage, quickly led the new linguistic authorities to recommend writers the use of Tagalog as the basis for the national language. The two languages have thus been competing with each other for decades. It was mainly thanks to the 1974 Bilingual Policy in Education, which provided for the use of both Filipino and English in the classrooms, that this dispute was almost definitely settled, notwithstanding the fact that linguistic choices are never —and will never be — neutral. For more information on the subject, see Manlapaz (2000, 187-202).
} 
of a rich tradition of Filipino poetry in English. This tradition could be dated back to the early days of the twentieth century, and it taught her how to decolonize the English language, that is, to use it in a specifically Filipino way. After all, English ceased to be the sole possession of the English a long time ago, which means that the use of English by any writer from a formerly colonized state should now be seen as an assertion of identity rather than as an indication of its loss. Bobis's poetical work could therefore be said to contribute to the consolidation of a new and rather more eclectic and liberating phase in the history of Filipino poetry: 'the open clearing' that, according to Gemino $\mathrm{H}$. Abad (2000, para. 16-20), began in the 1970s and has allowed Filipino poetry to keep on flourishing since then. ${ }^{3}$ To take Abad's words again (2000, para.18), it could be asserted that Bobis’s poetical works '[are] marked by a more heightened consciousness of language in the way it creates its own reality, together with a deep sense of the poem as artifice or a kind of double forgery: a forgery from language which itself is already a fiction of reality, and a forgery in one's own consciousness from the reality outside language.’

Last but not least, Merlinda Bobis also partakes in yet another interesting tradition, that of the Filipino radical theatre that, since its origins in the late 1970s, has dealt with areas of conflict and social tension, particularly in relation to issues of class, gender, and ethnicity. Among other things, this cultural movement took a prominent part in the fight against the dictatorship of Ferdinand Marcos. Theatre is, without any doubt, one of the artistic manifestations that holds greater critical potential because, as Gilbert and Tompkins put it, its 'capacity to intervene publicly in social organization and to critique political structures can be more extensive than the relatively isolated circumstances of written narrative and poetry; theatre practitioners, however, also run a greater risk of political intervention in their activities' $(1996,3)$. The real power of theatre 'lies in its ability to teach people how to think widely (Steadman 1991, 78), against and/or beyond established ideologies, political oppression, even political correctness. If, as contemporary poststructuralist criticism has demonstrated, (official) history

\footnotetext{
${ }^{3}$ A good and clear overview of Filipino poetry in English over the last one hundred years is given by Abad (2000, 327-31).
} 
systematically offers a strategic presentation of certain views and a suppression of others, (postcolonial/ feminist) plays use similar strategies of (re)presentation in order to disclose other-and othered-historical perspectives and thus question the authority of official discourses. Moreover, these plays also contribute to preserving pre-contact languages that are essential to oral traditions and their transmission of history and culture, thus establishing a linguistic gap (very often by using unglossed indigenous terms) that disproves notions of the infinite transmissibility of language (Ashcroft 1989, 72). Finally, they undermine the foundations of the cultural establishment by representing English since, as stated before, the fact that they use English does not necessarily mean that they endorse British values. To quote Gilbert and Tompkins again:

A dramatic focus on oral traditions opens up the possibility of challenging the tyranny of the written word through which many imperial languages claim their authenticity. By restoring to oral discourses their topology as performance pieces, theatre allows the orality of post-colonial languages to be fully realised, especially since each performance defers and deflects the authority of any written script. This descripted (performative) model of orality refers not to a language that has never been written, but to one which is unwritable at its moment of enunciation. $(1996,167)$

Yet, this critical potential often cuts both ways. Not only do these plays criticize the values upon which mainstream white culture relies, but they bring to the fore as well the battles and disagreements that characterized the time before western colonization. In other words, many of these playwrights, among whom Bobis could be included, do not offer a static or rarefied image of their peoples. They no longer perpetuate wrong conceptions of the past by confronting a harmonious (and consequently utopian) precontact period with the dismal post-contact past and present. On the other hand, this representation of multifarious disputes on both sides of the divide may also have some healing power because, however inflammable these conflicts may be, they also 'present an opportunity for dialogue, joint struggle, and provisional resolutions capable of releasing previously untapped social power' (Bodden 1996, 1). Indeed, joining in the struggle of other Filipino women activist writers and playwrights, such as the founders of women's activist movements like MAKIBARA, WOMEN or GABRIELLA, ${ }^{4}$ in her

\footnotetext{
${ }^{4}$ For more information on the origins, aims and strategies of Filipino radical theatre and activists see Bodden (1996, 24-6).
} 
poem-plays Bobis has insisted on denouncing past mistakes while also expressing her determined belief in reconciliation.

\section{Promenade and Cantata of the Warrior Woman}

Among other things, Merlinda Bobis's plays bring to the fore the fact that family and gender are fundamental components in the configuration of nationalism and a sense of national identity, thus corroborating Anne McClintock’s well-known assumption that nationalist discourses often rely on the trope of family in order to naturalize their particular constructions of community and belonging. As McClintock sees it (1993, 625), the image of family ascribed to national narratives presumes the subordination of women to men, and consequently strives to legitimate notions of the nation as something that should naturally imply hierarchy as well. Moreover, the very notion of family is related to notions of genesis and chronological development, which means that the ruling figures of the family are also entitled to formulate, direct, and control that development. In other words, nationalism has always been a gendered discourse, and cannot be understood, let alone questioned and undermined, without a theory of gender power.

Bobis’s poem-plays Promenade (1998b) and Cantata of the Warrior Woman (1998a) are excellent examples of such vindication, since these plays clearly show that class society, nationalism, and by extension all kinds of colonial processes, have been constituted and based upon the subordination of women to men. Therefore, the questioning and abolition of gender inequalities is absolutely central to the creation of a free and egalitarian society, one that transcends, and radically transforms, the patriarchal definitions of morality upon which the so-far official notions of individual and national identity have been erected. By putting forward a quest for national, collective and individual identity through reconstructing the lost voices of women in history, these poem-plays emphasize the importance of communication between self and other as the only way to give tolerance and peace a chance. Significantly, it is Bobis's occasional—and obsessive-reliance on rigid binarisms that paradoxically leads the reader to question their pertinence and validity. 
Promenade is a wonderful example of this. This performance poem was originally written as a poetry-dance drama for four actors: Woman Dark, Woman Light, Man Light, and Man Dark. To make confrontation and dualism even more obvious, they come from two different, or rather antagonistic, places: the other side of the mountain and the other side of the river. The emphasis on their shared otherness speaks for itself: no matter how strongly we try to detach self from other, the other is a quintessential part of our selves. As the Woman Dark concludes (1998b, 52):

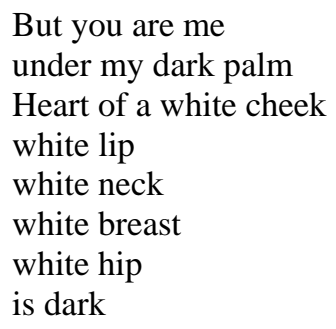

The lack of mutual knowledge and understanding can only lead to confrontation. Since each group assumes that the others have 'two left feet,' they cannot dance together.

In other words, the members of both groups refuse to communicate with one another, to the point that they all become left-footed dancers who dance out 'a Troy a Babylon/... Korea and Vietnam/ ... the Nicaraguan cry/ ... a Filipino coup/ ... Tibet Rwanda/ ...' (59-60), in a word, war. It is only when a new dance music is played and heard that 'the seams of history [can be] stitch[ed]' (64), that they can finally dance, and this conciliatory dance, full of sexual overtones, is regarded as something absolutely necessary, something they all wished and longed for but never dared to confess.

$\begin{array}{ll}\text { Woman Dark: } & \begin{array}{l}\text { Lover Lover } \\ \text { what is that new dance music } \\ \text { all about? }\end{array} \\ \text { Man Light: } & \begin{array}{l}\text { It is about the road to Ithaca } \\ \text { as far and empty as the eye can reach } \\ \text { as the song can reach }\end{array} \\ \begin{array}{ll}\text { Woman Dark: } & \begin{array}{l}\text { And who is playing that song? } \\ \text { Only no night: }\end{array} \\ \text { Only no one my dear }\end{array} \\ \text { Woman Dark: } & \text { But someone must play }\end{array}$




\section{because someone must dance \\ Man Light: $\quad$ Perhaps it is the wind or our wish for a wind playing it (62)}

Appearances can be terribly deceptive, and apparent opposites can end up being one and the same thing. Parallelisms and contrasts between syntactical structures (for example: Woman Dark: 'We did out-come the end/ Did we not? [51], versus Man Light: 'We could not out-come/ out-dance the end/ Could we? [66]), make it clear that nothing is what it seems to be. The only certain things are uncertainty and the need to keep on searching for answers, for bridges, for strings that unite rather than barriers that divide. Moreover, it would be no exaggeration to affirm that this outstanding reliance on visual binaries (male/female; and dark/light) also contributes to questioning discourses that naturalize gender hierarchies, while recuperating female subjectivities by showing that 'gender is an ideology mapped across the body in and through representation’ (Gilbert and Tompkins 1996, 212).

Bobis’s plays particularly question rigid and binary categorizations that have systematically relegated women to silence and invisibility, in the pre- and post-contact periods alike. They verify and authorize woman’s presence, vision and experience, mainly by focusing on the experience of compassion and care between women, and on the need for women to overcome the sense of rivalry that has been instilled by the patriarchy. Furthermore, Bobis's works often propose an escape from the established (male) space and the rigid taxonomies that conform it into a mythical—and therefore utopian-space (a place out of time and space) in which women can be free from male control and can survive and communicate without boundaries. Cantata of the Warrior Woman Daragang Magayon (1998a) could be offered as a good illustration of this. As Bobis has explained (1994, 117-29), this poem-play was an attempt to adapt the tradition of epic chanting (strongly identified with women in the Philippines) and to question and rewrite its mythical content, which in the past basically dealt with the deeds of male warriors. She recognized the subversive potential of this genre when she spoke of transplanting contemporary politics into the myth-now-rewritten and using 
this oral tradition as a more inclusive mode of resistance to oppressive regimes of all kinds.

The Cantata retells a traditional myth about Mount Mayon in Bikol, Bobis’s home region in southern Luzon Island of the Philippines. This well-known myth tells the story of Princess Daragang Magayon ('Beautiful Maiden’), who rebelled against the determination of her fate by the male elders, who simply regarded her as an item of war booty traded by powerful men. She refuses to become the commodified object that male authority trades at will, or the symbolic exchange that cements relationships between men, and decides instead to fight for her freedom and that of her tribe. So strong and subversive is her potential that her grave will eventually grow into an active volcano. However Filipino the topic may be, it is clear that the poem's feminist agenda might just as well be extrapolated to many other places, and most particularly to Australia, Bobis's host country. As has been well established, Australian culture has been constructed as an essentially masculine one. Within this domain, woman has been relegated to a marginal position where she has been given neither place nor voice. She has often been excluded as the subject of representation, and has been instead spoken for, to the point of becoming, to quote Shaffer's expression, 'the colonised sex' (1990, 8) in a predominantly phallocentric culture. ${ }^{5}$

Significantly enough, throughout the poem-play, the protagonist refuses to be objectified ('I am more than body./ I am heart. I am mind./ I am mine. I am mine' [86]), to remain fixed within a single role, and by extension to be contained and imprisoned by rigidified naming. She soon realizes that she cannot possibly identify with the several names she has been given: 'Beautiful Maiden,' ‘The Betrothed of Pagtuga' (the

\footnotetext{
${ }^{5}$ One of the reasons for the dominant role ascribed to man in Australia lies in the special relationship that he maintains with yet another important leitmotif of the Australian tradition: the land. Much of the socalled Australian myth of nation responds to the male desire to control and possess an alien land in order to reaffirm his position as master and conqueror. Meanwhile, the western conception of the land as something female (the so-called 'mother earth') places woman both outside and within the Australian bush tradition. As Shaffer remarks, woman functions as a metaphoric sign for the Australian landscape: functioning as the fetishist Other, the land-as-woman is represented as the negative component that man must appropriate in order to reassert his identity. She is, in Shaffer's words, the 'harsh, cruel, threatening, fickle, castrating mother. She is dangerous, non-nurturing and not to be trusted' $(1990,62)$.
} 
enemy chief), and 'The Young of Makusog' (her father). These are not 'her' names. Male authorities have imposed them on her, with the sole purpose of subjecting and reducing her to a fixed image they can easily manipulate and control.

Once they called me Daragang Magayon, a name that means Beautiful Maiden.

A curse lurked in that name.

I was hair, eyes, lips, breasts and feet of fire. I was holy. I was religion. Maiden-bound, I was desired; bold hunter's bounty, game and fruit trembling close to seeking lips and teeth that sink to tame.

I was. I was a name. (77)

Daragang Magayon knows that it is the sense of reality and value of her name-givers, and not her own, that strives to take hold of her. She must resist the temptation to acquiesce and get therefore entangled in their inflexible definitions, which prevent her from inventing herself.

\author{
How easy then to succumb \\ to the cosy little room \\ that makes a given name; \\ the space is cleared and cut \\ for you. You can grow \\ without wondering how far. \\ Ay, only to that other end, \\ that final letter \\ crouched against the wall. (97-8)
}

To escape this lethal confinement, she 'unnames' herself, thus doing away with her former condition of embodiment of existing signs in order to become 'The Nameless One Who Is All Names’ (78), that is, the creator of fluid and ever-changing meanings.

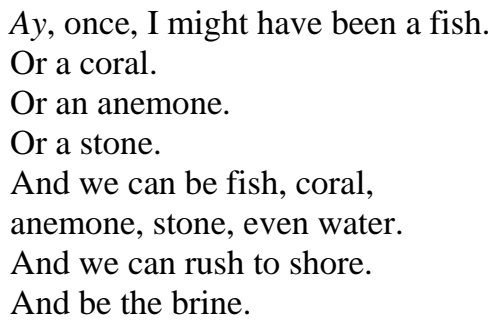


And leap to air.

And be the wind.

How we speak

many names

beyond old names.

We touch skin

and shed skin.

We remember self

and find another. (144)

This passage could also be said to illustrate Bobis's difficult creative journey. As she herself has affirmed when discussing this controversial poem-play, 'I also attempted to unname/rename my Self and my chosen literary form by breaking restrictive traditions. I refused to be 'fixed' under absolute definitions of gender and ethnic background' (1994, 118). Artists endowed with what might be called 'a hyphenated identity' are often misunderstood and attacked by people who insist on clinging to a rigid and monolithic concept of culture and selfhood. For many Asian-Australian women artists, and Merlinda Bobis is no exception, looking/sounding too Australian, that is, too assimilated, often leads to accusations of having betrayed her people and abandoned her roots. ${ }^{6}$ On the other hand, attempting to keep the links with the original community, cultural history, and ethnic customs, may lead others to deny the Asian-Australian woman the right to claim an 'Australian' identity.

The Cantata of the Warrior Woman recreates, in this context, a traditional epic by subverting its conventions. In other words, this poem-play is a hybrid text that openly defies long-established cultural and generic divisions and classifications. On the one

\footnotetext{
${ }^{6}$ After watching Bobis's major performance in Australia, a well-known Manila critic accused her of having hybridized, and thus betrayed, tradition and co-opted with the West. He argued that the West should not have been able to make sense of the performance, because their words are too limited to understand the Other, and went as far as to assert that, if westerners could understand the work, then it was no longer valid for Filipinos (Bobis 1994, 127).

${ }^{7}$ As Tseen-Ling Khoo claims, Asian-Australian women's writings have often been underestimated by critics because, on many occasions, 'reviews and readings are carried out against a backdrop of the Australian popular cultural perception of Asia as economic frontier, and Asian peoples as tourists or potential business partners, if not refugees' (2005, para.1). It is also undeniable that Australia's former 'white'/ xenophobic attitudes can still sometimes stand in the way of the production of sound and nonbiased analyses of works by non-Anglo-Celtic authors. In particular, Asian-Australian women writers find it especially difficult to see and express themselves as 'Australian' due to Australia's long history of rejection of and discrimination towards Asians. Moreover, the use of the term 'ethnic writing,' although more and more in disuse, can at times be taken as a synonym of 'marginal' or 'second-class writing' or, to take Linda Carroli's words, "as an agglomeration of minority and esoteric experience that has no real value to the professionalized arts of the dominant culture" $(1994,333)$.
} 
hand, it contains elements that clearly connect it with Filipino indigenous and other traditional epics: it is a long narrative poem; war and the healing process that follows are its main subjects; it is written in elevated/ archaic style; the Warrior Woman is depicted against both natural and supernatural worlds that connect her with both history and myth; the fate of the tribe depends on the hero's - in this case heroine's-actions. Nevertheless, this is not a traditional epic. Tradition should also be revised and questioned: 'What wisdom in tradition/ that can kill' (99). To begin with, and in clear contrast with most traditional epics, which put the emphasis on courage and heroism in combat, the Cantata deplores war and the use of violence, of which helpless women and children are usually the victims. In this poem-play, the protagonist feels compelled to rebel against such treatment, which deprives women of their freedom and their right to play an active role in history, while denying them the possibility of receiving any kind of social recognition.

How wide our battlefield, but how narrow our palms, always unfurled, always vulnerable.

The master decides there are no fists for us.

No wonder, even in our dance, we turn only with open hands. No clutching of the wind for us; leave all the clutching to the sons. (128)

The Warrior Woman fights against those who glorify war and conquest ('There is always another war/ after every war' [135]), and brings to the fore the suffering and resilience of women:

But all of us suffer both bed and blade. All of us daughters waiting to be dragged by strange hands. All of us unarmed and crouching from the dark. All of us who are baptised by our wombs. And cut in its name. All of us who are not sons. (130)

Women's persistent endurance is, more often than not, much more heroic than men's 
momentary courage at war. The warriors who have fought in battle are praised and immortalized in great epics, whereas the women who kept things going while the men were away, and who must cope with their irreparable losses after the war ('They say we have won./ But I am looking for my son’ [135]), are relegated to oblivion. Women’s fundamental contribution to the survival and healing of the nation can no longer be ignored. The very notion of the 'heroic' is therefore put to the test.

\author{
When the blades are buried, \\ there are more heroes. \\ And theirs is not courage \\ of a sudden flash \\ surging when the foe is close, \\ not the tightening of flesh \\ for that lethal blow. \\ It is a courage long \\ and drawn-out like a breath, \\ air endlessly pursuing air. (135)
}

The Warrior Woman is finally caught in a dilemma: to fight or not to fight. However much she dislikes war, it seems there is no other way out, since she wholly refuses to 'buy’ peace by becoming the enemy’s wife.

\author{
The Elders talked about my womb \\ again \\ and sons, the likes of Pagtuga. \\ Meanwhile, the pirates \\ hunted our tribe every season, \\ but father was too old \\ to battle them. Too much blood \\ pounded on our doors. (124) \\ I would not be fodder \\ for old men who live to hunt. (107) \\ I can be warrior at fourteen \\ like all the other boys. \\ Did you not call me \\ The Young of The Strong One? \\ Did you not know \\ my cunning in the hunt? \\ Give me a fair battle now. \\ If I should die, \\ let it not be by my other name, \\ Daragang Magayon, \\ that only waits to be uttered \\ by the pulse of his loin. (129)
}


The fact that the main character is not a hero but the Warrior Woman also contributes to the controversial nature of this work. Most heroines in traditional narratives, Filipino folk epics being no exception, are commonly depicted as secondary characters. In these tales, the hero always plays the active and courageous part, whereas women remain powerless and passive. Merlinda Bobis has managed to counter this gender distinction by offering a female hero who resembles heroic characters in Filipino history. As Bobis says:

From the babaylan (shaman) of precolonial Philippines to the amazona (Filipina guerilla of the Left) of contemporary times, we have a tradition of warrior women who led their own epic lives. The female guerillas, peasant revolutionaries and union organisers -who have defied the colonising Spaniards, Americans, Japanese and, more recently, the Filipino politicos and military- can easily replace the masculine model of the epic hero. Indeed, one of my country's most celebrated heroes Gabriela Silang, who fought against the Spaniards in the mid-eighteenth century, became one of my major inspirations. (1994. 121-22)

The Cantata, therefore, defies well-known epic conventions while apparently relying on them. Again, appearances can be rather deceptive. This poem-play makes it clear from the very beginning that the Warrior Woman is the bard who will tell the story, and its opening is no different from that of most traditional epics that begin in medias res, during the preparation for battle. Yet, in this case it is not a god, but the heroine's own distaste for war that paralyzes her. Moreover, if the prologue in most traditional epics is an invocation to the muse, gods or spirits, here the prologue is nothing but a statement of the play's main argument, namely, the rejection of logocentrism or, to put it in simpler terms, the questioning of either/or distinctions and fixed meanings. Ambiguity of form is yet another significant issue. The Cantata is generically ambiguous, since it cannot be categorized as being simply epic, dramatic, or lyric. It is all three in one. As Roger Sworder puts it (in Bobis 1994, 124):

What you were doing was realising something more than epic -more like drama. But it is not truly dramatic, because you have only one actor. And because the dimensions of personality that you are exploring are not personal at all, it is not lyric either, although it is revelatory of the innermost feelings of the character. There is nothing particular about your Warrior Woman. She is the personification of 'the female,' The fact that your work is about 'the female/ feminine' rather than 'this female' is probable what gives it its epic spirit. 
In keeping with this statement, the Cantata could be offered as an example of hybridized theatrical discourse. On the one hand, it incorporates traditional/ indigenous elements, which involve a departure from the techniques and assumptions of realism, for so long the ruling mode of conventional western plays. On the other hand, it vindicates the validity — and pertinence — of other modes of representation. This consequently affects the play's content, structure and style, and its overall meaning and effect. Traditional/indigenous enactments are not only mnemonic devices that help preserve history, but are also effective strategies for maintaining cultural difference through specific systems of communication (aural, visual, and kinetic) and through specific values inherent to local and pre-contact customs (Gilbert and Tompkins 1996, 54).

One of those empowering traditional/indigenous elements is ritual. Ritual plays have the power to situate their subjects and actions outside western epistemologies, thus escaping the teleological assumptions of linear time. Furthermore, this non-naturalistic theatre denounces how space is constructed by culture and power, and strives to make the processes of participation conscious and powerful, as they become part of a larger communal—and political_-project of liberation from different kinds of cultural oppression. As Gilbert and Tompkins put it (1996, 76-8):

\footnotetext{
A theatre practice informed by ritual aims to do more than merely keep the spectator aesthetically engaged. Like other forms of political theatre, it foregrounds belief systems and demands some kind of active response. And while ritual is a central way of transforming and simultaneously maintaining the spiritual and social health of a society, it has also shaken the geographic boundaries that colonisation erected, as illustrated throughout the [different forms of] diaspora by the increasing emphasis on ritual-based traditional enactments in theatre practice and in more general forms of cultural expression.
}

Music and dance also play a fundamental role in this critical project, and are often a quintessential part of ritual. Transformations of the postcolonial female body are often theatricalized through rhythmic movement such as dance, which highlights the performing body, both as 'the site of knowledge-power' and as 'a site of resistance' (Grosz 1990, 64). 
Splitting the focus from other sorts of kinetic and linguistic codes, dance renegotiates dramatic action, Gilbert and Tompkins have claimed (1996, 239-40), thus reinforcing the actor's corporeality, especially when it is culturally laden. Dance is a form of spatial inscription and thus a way of embodying and defying the domineering aspects of western culture and thought. Moreover, dance recuperates postcolonial subjectivity by centralizing traditional and non-verbal forms of self-representation. Located within a dramatic text, dance often denaturalizes theatre’s signifying practices by disrupting narrative sequence and/or genre. In other words, dance draws attention to the constructedness of all dramatic and, by extension, artistic representation, thus pointing to its potential as an alienating device in the Brechtian sense. Yet, it is also worth mentioning that in many plays, like the ones discussed here, traditional dances and styles of movement are hybridized with western form and fashion, so that the dance presented to the audience is no longer a reified traditional art but a staged artistic process. This does not deprive such dances of their power to function as acts of cultural retrieval, and nor does it turn them into a sign of acculturation, as some primitivist critics have claimed. On the contrary, these hybrid dance forms express a polyvalent and versatile identity that takes tradition into account while refusing to be confined under the sign of 'authenticity.'

Rituals and ritual dances are a quintessential part of the Cantata. Not only do they help the action unravel, but they also add further layers of symbolism and meaning that the reader/spectator must try and decipher so as to be able to integrate them into an everchanging but ultimately coherent whole. The repetitive and circular nature of rituals is clearly brought to the fore. Yet, repetition also implies variation. 'This has been done before./ It must be done again today/ and tomorrow. Rituals repeat/ themselves as in chanting./ Never a break between’ (99). Different circumstances but the same injustice, this poem-play invites us to conclude. It is also made clear from the very beginning that women and men have separate ritual ceremonies, and that they are of a very different nature. Men’s ceremonies are often celebratory. They celebrate the power and control they exert over all the other members of the community, especially women, as when Makusog and Pagtuga celebrate the Sandugo, whereby they draw and drink each 
other's blood in ritual to their new deal and to seal Daragang Magayon's fate as the betrothed of his father's former enemy. Women's rituals, on the contrary, represent the female condition as one of imprisonment, while simultaneously or, by turns, enacting fantasies of women's power and capacity to disrupt and defy the very confinement that has been imposed upon them. The beauty rite that the midwife must enact when the princess is born speaks for itself: women, no matter how high their social position may be, are denied the right to think and are reduced to the condition of bodies, whose only function is to please the ruling males and bear them new (male) warriors and (female) bodies. 'A heavy piece of wood on the brow/ and another pressed/ against the back of the head/ to flatten the skull -there./ Pity the newborn. The pressing/ wood/ will break her skull.' (99). On the other hand, although the Kibang (183-93) makes it clear that it is women that have to take the mortal risk to ask the oracle (it is the warriors that ultimately ask/tell Daragang Magayon to undertake the pilgrimage to the shore for the divination), it also assigns them powers and wisdom of which men seem to be deprived, as when Magindara, the oracle, says to the princess: 'You are nameless./ Yet you own all names.' (189). 'A dead fish' is the right answer to the oracle's riddle 'What fish does not swim against the current?' As soon as Daragang Magayon is able to utter it, she undergoes a fantastic metamorphosis. All of a sudden, she turns into an older, and therefore wiser, woman, till she is again allowed, mainly thanks to the other women's prayers in the ritual of the Sakom, to come round, recover her previous appearance and, most important of all, persevere in her fight against the wishes of the male elders, who only want her to marry the enemy who is to subdue and annihilate her and her people. Death awaits all of them, but after the massacre the mountain becomes and enacts 'the ascent of rage/ and grief of a whole tribe.' and is 'deeply furrowed/ by the universal scar.' (197), thus becoming the ultimate embodiment of the power and need of subversive resilience and resistance. Reconciliation is to be desired and sought but so far it still is a remote possibility: 'Flight is song/ on four wings./ The fifth wind/ does not sing.' (200).

By introducing and interweaving such traditional elements as epic chanting, unglossed indigenous words, ritual and dance the Cantata has managed to become a successful 
attempt to re-invent both western and indigenous theatrical discourses, and thus to question all kinds of clear-cut divisions and binarisms. Merlinda Bobis has hybridized tradition, has transcended the rigid framework of any particular culture to create her own form, that is, to create herself.

Creative blood runs into multiple arteries and veins, while sifting then picking up new and even alien treasures along the way. Then, when it has made its full trip to return to the heart, it cannot pretend that it is still of a preciously pure consistency-or of a definite identity or name. In its multiplicity of urges - steeped in tradition, contemporaneity and various cultures and tongues_creative blood might as well be a nameless hybrid. (Bobis 1994, 128)

Significantly, when Daragang Magayon learns how to dance with the rest of the women in the tribe she also learns the most important lesson. She is no longer superior to them. As soon as the princess remembers with them, dances with them, she gets rid of all the restrictions imposed on her by male authority and is able to transcend all differences to become one with them.

Dance, in this case, is not only a mode of empowerment for oppressed characters, but also an equalizer, a physical and social force that does away with hierarchies even as it highlights the specific idiosyncrasy of the various participants. Despite their differences of class, occupation and age, the women dancers enact a vision of unity, however utopian. This explains why these ritualistic dances are regarded as a threat by the ruling male authorities, whose ability to keep social order mainly depends on the preservation of social divisions. The women on stage celebrate this harmonious unity exclaiming:

She is no princess.

She is no beautiful maiden.

She is not the young of her father.

She is not the betrothed

of the murderer.

She is water.

She is stone.

She is bird. (153)

Life, like truth, the Cantata seems to assert, is never monolithic. It is tremendously complex, ever-changing and fluid. If we insist on applying our own cultural parameters, 
rules and taxonomies to the study of other cultures, we will never manage to communicate with them and, by so doing, get to know ourselves, because the 'other' is also part of ourselves, however hard we may try to repress and deny it: 'Blindness and fear;/ fear and blindness,/ what closest kin’ (91). In the context of this complex world society, the role of the writer/performer is that of a bridge, a translator who can go beyond apparent differences to search for unity. In the poem-play analyzed here, women seem to be better equipped to make this discovery. To quote the words uttered by Sirangan, the princess's maid:

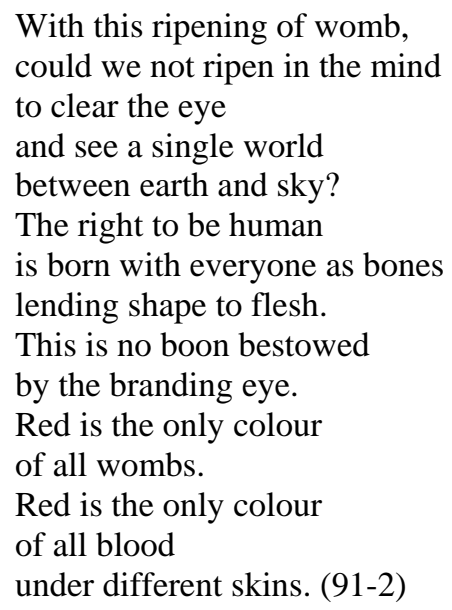

Yet, sisterhood is not the end of the story. The main issue that the Cantata brings to the fore is that fear does not men and women alike from their obligation to be ethical, that is, to engage in a communal dance, in an open-ended dialogue with the world and the others, to open themselves to the experience of alterity that, alone, will let us grow and make a better world possible. Daragang Magayon verbalizes what some human beings have known for centuries:

\footnotetext{
I toast to all humanity.

Small and big, the same worth.

Big and small, the same use.

This was their tigsik before.

This is still our toast today.

(...)

In the years after that dance

in the ritual of the Halya,

I saw how all hands

of different colours
} 
Push the earth to turn.
One hand could bind all hands,
but the world spins on -
The pulse unknots the fear.
This drum beats,
breaks, burns the cord. (93-94)

Not only does Merlinda Bobis embody the push and pull between different cultures and languages but also, and more importantly, she ultimately transcends these barriers. For her, it is in this liminal space, to take Homi Bhabha's well-known words, that 'we can speak of Others and Ourselves. And by exploring this hybridity, this Third Space, we may elude the politics of polarity and emerge as the others of ourselves' $(1988,8)$. Since there are no monolithic truths, we cannot possibly be in absolute control, and the subject is in constant dialogue and transformation. Similarly, the multiple histories that circulate in postcolonial societies (the Philippines, Australia, and so on) overlap, intersect and compete with one another. They can be neither fused into a singular national (or any other kind of) narrative nor completely separated from one another or from their own particular contexts. History remains a site of struggle and contention, a hybridized discourse laden with contradictions and conflicts.

Consequently, solutions are to be made, not learned, hence the need to create 'ethical' discourses that incorporate the stories, desires and frustrations of the multitude of people who make up a nation or community. In short, political and cultural pluralism should be enforced, since this is the only way in which univocal and oppressive ideologies (patriarchal, colonial, and so on) can be dismantled so as to give a chorus of never-ending voices the chance to make a claim for shared authenticity and authority, for mutual tolerance, understanding, and care. The ethics of care is, therefore, the ethics of the future. It has often been taken up as the ethics of feminism. Yet, to claim this ethics for one gender will be absurd, since we will be doing precisely what we are trying to discard and condemn. The ethics of care are, and should be, not only genderless, but also trans-gender, trans-national, trans-cultural. As citizens of this difficult, complex and globalized era, we should try and cling to a code of ethics that makes comprehension and communication possible along such 'trans' lines. The question is: Will the pulse unknot the fear? Will this drum beat, break and burn the cord? 


\section{Acknowledgements}

The research carried out for the writing of this paper was financed by the M.C.Y.T. (Ministerio de Ciencia y Tecnología). D.G.I./FEDER, Proyecto HUM2004-00344/FILO. A previous and rather shorter draft of this paper was presented at the $8^{\text {th }}$ Biennial EASA Conference: Re-visions of Australia: Histories, Images, Identities, which was held in September 2005 in Debrecen, Hungary, and will soon be published in Hungarian Journal of English and American Studies with the title 'Merlinda Bobis's Re-evaluation of Personal and (Multi)National Ethics and Identity: Cantata of the Warrior Woman.'

\section{Reference List}

Abad, G.H. 2000, 'One Hundred Years of Filipino Poetry: An Overview,' World Literature Today, vol. 74, no. 2, 327-331.

Arnold, M. (1882) 1992, Culture and Anarchy and Other Writings, Cambridge University Press, Cambridge.

Ashcroft, B. 1989, 'Constitutive Graphonomy: A Post-colonial Theory of Literary Writing,' Kunapipi, vol. 11, no. 1, 58-73.

Bhabha, H. 1988, 'The Commitment to Theory,' New Formations, vol. 5, 5-23.

Bobis, M. 1994, 'Re-inventing the Epic: Notes on Adapting a Traditional Genre,' Australian Drama Studies, vol. 25, (October), 117-29. 1998a, 'Cantata of the Warrior Woman Daragang Magayon,' in Summer was a Fast Train without Terminals, Spinifex Press, Melbourne, 67-200. 1998b, 'Promenade,' in Summer was a Fast Train without Terminals, Spinifex Press, Melbourne, 45-66.

Bodden, M.H. 1996, Frontiers. Boulder, vol. 16, no. 2-3, 24-26.

Booth, W.C. 1988, The Company We Keep: An Ethics of Fiction, University of California Press, Berkeley.

Bulbeck, C. 1998, Re-Orienting Western Feminisms: Women's Diversity in a Postcolonial World, Cambridge University Press, Cambridge.

Carroli, L. 1994, 'Out of the Melting Pot into the Fire,' Meanjin vol. 53, no. 2, 327-36.

Derrida, J. 1989, Memoires for Paul de Man, trans. J. Culler, C. Lindsay, and E. Cadava, Columbia University Press, New York. (1991) 1995, The Gift of Death, trans. D. Wills, University of Chicago Press, Chicago. 2001, On Cosmopolitanism and Forgiveness, Routledge, London.

Falzon, C. 1998, Foucault and the Social Dialogue: Beyond Fragmentation, Routledge, London and New York.

Ghandi, L. 1998, Postcolonial Theory: A Critical Introduction, Columbia University Press, New York.

Gibson, A. 1999, Postmodernity, Ethics and the Novel: From Leavis to Levinas, Routledge, London and New York.

Gilbert, H., and Tompkins, J. 1996, Postcolonial Drama: Theory, Practice, Politics, Routledge, London and New York.

Gilligan, C. 1982, In a Different Voice: Psychological Theory and Women's Development, Harvard University Press, Cambridge, Mass. 1995, 'Hearing the Difference: Theorizing Connection,' Hypatia 10.2 (1995), 121-26.

Grosz, E. 1990, 'Inscriptions and Body-Maps: Representations of the Corporeal,' in Feminine/ Masculine and Representation, eds T. Threadgold and A. Cranny-Francis, Allen \& Unwin, Sydney, 62-74.

Haney, D.G. 2002, 'Ethics and Identity: Postcolonial Feminist Perspectives,' in Ethics and Subjectivity in Literary and Cultural Studies, eds William S. Haney and Nicholas O. Pagan, Peter Lang, Bern, 143-158.

Hekman, J. S. 1995, Moral Voices, Moral Selves: Carol Gilligan and Feminist Moral Theory, Polity Press, Cambridge.

Khoo, T. n.d., 'Someone’s Private Zoo: Asian Australian Women's Writing' [Online]. Available: http://www.calgary.ca/UofC/eduweb/engl392/492a/articles/zoo.html [Accessed 18 March 2005]

Kotte, C. 2001, Ethical Dimensions in British Historiographic Metafiction: Julian Barnes, Graham Swift, Penelope Lively, Wissenschaflicher Verlag Trier, Trier. 
Lanot, M.Pl. 1997, 'Poetry as a People’s Right is Also a Woman’s Right,' Heritage [Online], vol. 11, no. 1 (Spring), 35-6.

Leavis, F.R. 1933, Culture and Environment: The Training of Critical Awareness (with Denys Thompson), Chatto \& Windus, London; Oxford University Press, Toronto. 1948, The Great Tradition: George Eliot, Henry James, Joseph Conrad, Chatto \& Windus, London; Clarke Irwin, Toronto. 1982, The Critic as Anti-Philosopher, ed G. Singh, Chatto \& Windus, London.

Levinas, E. (1961) 1969, Totality and Infinity, trans. A. Lingis, Duquesne University Press, Pittsburgh, PA. (1974) 1981, Otherwise Than Being or Beyond Essence, trans. A. Lingis, Martinus Nijhoff, The Hague.

Manlapaz, E.Z. 2000, 'Literature in English by Filipino Women,' Feminist Studies, vol. 26, no. 1, (Spring), 187-201.

McClintock, A. 1993, 'Family Feuds: Gender, Nationalism and the Family,' Feminist Review, vol. 44, (Summer), 62-5.

Miller, J.H. 1987, The Ethics of Reading: Kant, de Man, Eliot, Trollope, James, and Benjamin, Columbia University Press, New York.

Nussbaum, Martha C. 2001, Upheavals of Thought. The Intelligence of Emotions, Cambridge University Press, London and New York.

Schaffer, K. 1990, Women and the Bush. Forces of Desire in the Australian Cultural Tradition. Cambridge University Press, Cambridge.

Spivak, G.C. 1988, 'Can the Subaltern Speak?,' in Marxism and the Interpretation of Culture, eds C. Nelson and L. Grossberg, University of Illinois Press, Chicago, 271-313.

Steadman, I. 1991, 'Theatre Beyond Apartheid,' Research in African Literatures, vol. 22, no. 3, 77-90.

Talpade Mohanty C., Russo, A., and Torres, L. (ed.) 1991, Third World Women and the Politics of Feminism, Indiana University Press, Bloomington. 